\title{
FELONY MURDER AS A FIRST DEGREE OFFENSE: AN ANACHRONISM RETAINED
}

The felony murder doctrine occupies an anomalous and much criticized position in the American law of homicide. Where murder is divided into two degrees of culpability, felony murder is considered a first degree offense. ${ }^{1}$ Yet unlike other offenses of the same degree, felony murder does not depend on the relation between the lilling and the offender's mental state : the homicide need only occur in the commission of a prescribed felony. ${ }^{2}$ All other murders carrying equal punishment require that the homicide be willful, premeditated and deliberate. $^{3}$ This requirement accords with a basic principle that punishment of homicide be proportionate to culpability measured by mental state.

1. This is true of thirty-six American jurisdictions recognizing two degrees of murder. See the statutory compilation in Michael \& Wechsler, Criminal Law and ITS AdMinistration 1271-72 n.6(A), (C) (1940).

Two jurisdictions recognize three degrees of murder. One of these, Florida, imposes first degree punishment on felony killings arising out of arson, rape, robbery, burglary, abominable and detestable crime against nature or kidnapping, third degree for those wecurring in the commission of any other felony. FLA. STAT. ANs. $\$ 782.04$ (Supp. 1955). The ather, Minnesota, does not treat felony killings as first degree murder but provides second degree punishment for those arising out of rape, assault with an intent to commit rape, indecent assault or sodomy and third degree for those occurring in the course of any other felony. Minn. Stat. ANN. $\$ \$ 619.07, .08$, .10 (Supp. 1955).

Ten jurisdictions do not recognize degrees of murder. In five, felony killings are expressly punishable as murder by statute. GA. Cone ANN. tit. 26, \$\$ 26-1002, 1009 (Supp. 1955) (murder when underlying crime is punishable by death or confinement in penitentiary and when killing committed in "prosecution of riotous intent") ; LA. REv. STAT. Aws. $\$ 14: 30$ (Supp. 1955) (aggravated arson, aggravated burglary, aggravated kidnapping, aggravated rape, robbery); Mrss. CoDE ANN. \$ 2215 (Supp. 1954) (arson, rape, robbery, burglary); OkLa. Stat. ANn. tit. 21, $\S 701$ (Supp. 1955) (commission of any felony); S.D. CODE $§ 13.2007$ (Supp. 1952) (commission of any felony). There is no statutury prescription of felony killings in the other five no-degree jurisdictions. IrL. ANN. STAT. c. 38, § 358 (Smith-Hurd 1955) ; Ky. Rev. Stat. ANN. $\$ 435.010$ (Baldwin 1955); ME. Rev. Stat. ANN. c. 130, \& 1 (Supp. 1955) ; S.C. Code $\$ 16-51$ (Supp. 1955); 2 TEx. PEN. Cope AnN. art. 1256 (Supp. 1956). However, case law in these jurisdictions indicates that felony killings are subject to murder convictions. See, e.g., People v. Pierce, 387 Ill. 608, 57 N.E.2d 345 (1944) ; Simpson v. Commonwealth, 293 Ky. 831, 170 S.W.2d 869 (1943); State v. Merry, 136 Me. 243, 248, 8 A.2d 143, 146 (1939); State v. Judge, 208 S.C. 497, 505-06, 38 S.E.2d 715, 719 (1946); Miers v. State, 157 Tex. Crim. 572, 251 S.W.2d 404 (1952). See text at notes 23-24 infra.

2. Most statutes list arson, rape, robbery and burglary as the prescribed felonies. Michael \& Wechsler, op. cit. supra note 1, at 1271 n.6(A). See, e.g., Ala. Code ANn. tit. 14, § 314 (Supp. 1955); Mich. Stat. AnN. $\$ 28.548$ (Supp. 1955).

3. Although formulations of the premeditation and deliberation requirement differ, the majority of jurisdictions uses these words. MICHAEL \& WECHSLER, op. cit. supra note 1 , at 1270-71 n.5. See, e.g., Iowa Code ANn. $\$ 690.2$ (Supp. 1956); Mont. Rev. Cones ANN. § 94-2503 (Supp. 1955). 
Recent criticism has primarily focused on extensions of the felony murder doctrine. ${ }^{4}$ The history of the law of homicide indicates, however, that felony murder itself is incompatible with the concept of culpability. 5 This inconsistency has been the major obstacle to commentators who have criticized extensions of the doctrine, for they have sought to read a requirement of mental state into a rule which does not demand a showing of intent to kill. ${ }^{\circ}$ A solution to the problems which both felony murder and its extensions raise may more likely be found in an analysis which tests the validity of the doctrine itself.

Although a concept of culpability was not an element of homicide in early common law, its importance was recognized by the end of the thirteenth century. Originally all killings were homicides regardless of attendant circumstances, and all homicides were capital offenses. ${ }^{7}$ In 1278 , however, a statute made pardon available to the offender who killed in self-defense or by "misadventure." Later, some homicides committed under color of law became justifiable. ${ }^{9}$ Although the defendant who escaped capital punishment by proving self-defense or misadventure nevertheless suffered conviction, forfeiture and the expense of obtaining a pardon, one who killed under color of law was simply not guilty of homicide. ${ }^{10}$ Thus culpability, introduced as a basis for post-conviction mitigation of punishment, became a substantive ground for absolving guilt.

Further development of culpability as the criterion of punishment for homicide was impeded by the practice of "benefit of clergy" which allowed the literate defendant to escape capital punishment even if his killing was neither justifiable nor pardonable. Attaching to all capital offenses, ${ }^{11}$ the benefit was

4. See, e.g., Notes, 59 Drck. L. REv. 183 (1955) ; 31 IND L.J. 534- (1956) ; 54 MrCH. L. REv. 860 (1956). First degree murder conviction has been held proper where the victim of a robbery killed defendant's escaping accomplice while chasing him in a direction different from that taken by defendant, Commonwealth v. Thomas, 382 Pa. 639, 117 A.2d 204 (1955); and where the death of defendant's accomplice was caused by his own neglect in setting fire to an empty house, Commonwealth v. Bolish, $381 \mathrm{~Pa} .500,113 \mathrm{~A} .2 \mathrm{~d} 464$ (1955).

5. See text at note 33 infra. See also Norris, The Felon's Respansibility for the Lethal Acts of Others, 105 U. PA. L. Rev. 50 (1956).

6. See, e.g., Crum, Causal Relations and the Felony Murder Rule, 1952 Wast. U.L.Q. 191, 208-10; Note, 31 IND. L.J. 534, 536 (1956).

7. See 2 Pollock \& Maitrand, History of English Law 473 (2d ed. 1905) (hereinafter cited as Pollock \& Maitiand) and 2 Holdsworth, History of Englise Law 358-59 (4th ed. 1936) (hereinafter cited as HoLDSwORTH), noting that the executioner carrying out a lawful sentence was excepted from this extreme liability.

8. Statute of Gloucester, 1278, 6 Enw. 1, c. 9. Pardon was previously available in such cases; this statute, however, formalized the procedure for obtaining it. See 2 PoLIock \& MartLand $480-81$. The royal pardon thus authorized remained discretionary although it later could be obtained as a matter of course. See ibid.; 2 HoLdsworre 359.

9. In 1293, a statute made not punishable and hence justifiable the killing of a trespasser resisting expulsion by foresters, parkers and warreners. 21 Evw. 1, No. 2 (1293).

10. 2 Pollock \& Maitland 479-81; 3 Stephen, History of the Crminal Law of England 40-41 (1883) (hereinafter cited as Stephen).

11. The benefit attached to all felonies. Gabel, Benefit of CleRgy in England in the Later Mrddle Ages 116 (1929) (hereinafter cited as Gaber). In England, all felonies 
designed to insure Church trial of clerics by transferring their prosecution from Crown jurisdiction. ${ }^{12}$ Since literacy was unknown among lay persons, a reading test was one method of determining whether an offender was entitled to invoke the benefit. ${ }^{13}$ By the end of the fourteenth century, satisfying this test became in itself sufficient proof of clericity. ${ }^{14}$ But since the ability to read was no longer confined to clerics, any literate offender, lay or cleric, could escape Crown jurisdiction. ${ }^{15}$ Submission to Church jurisdiction gave absolute immunity from capital punishment. ${ }^{16}$ And likelihood of acquittal was increased because ecclesiastical courts were more lenient than lay tribunals. ${ }^{17}$ In allowing a preferred citizenry whose punishment was dictated by the unrelated factor of literacy, the benefit of clergy disregarded the circumstances of the lilling and thus prevented uniform application of culpability as the sole measure of punishment.

Culpability gained full effect in the fifteenth and sixteenth centuries when homicide was divided into two offenses and the benefit of clergy removed from the one characterized by criminal mental state. A series of statutes finally removed the benefit entirely from the more culpable homicides, denominated murders. ${ }^{18}$ Homicides other than murders retained the benefit. The two were distinguished on the basis of the offender's mental state. If one killed with malice aforethought, the required mental state. he was guilty of murder; the same act without malice aforethought was only criminal homicide. ${ }^{19}$

except petty larceny were capital crimes through the eighteenth century. 3 STEPEEN 75. But of. Dalzell, Benefit of Clergy In America 29 (1955) (hereinafter cited as DalzFLL), indicating that the benefit may not have attached to high treason, some forms of arson, lying in wait on the highway, and ravaging the countryside, but not revealing dates under discussion.

12. Dalzell 11 ; Gabel 7.

13. GABEL 30.

14. Dalzell 16; Gabel 68-70.

15. GABEL 70. During the fifteenth century, the reading test made the benefit of clergy availahle to a considerable number of laymen. Id. at 118 .

16. Dalzell 10; Gaber 117.

17. Dalzell 11 ; Gabel 117-18.

18. 12 HeN. 7 , c. 7 (1496); 4 HEN. 8 , c. 2 (1512) ; 23 HEN. 8 , c. 1 , s. 3 (1531); 1 Enw. 6, c. 12, s. 10 (1547).

19. Murder, or murdrum, had appeared in the law prior to these statutes. Originally meaning a secret homicide, murdrum was probably later thought by the popular mind to indicate the worst kind of killing. 2 Pollock \& Martuand 485-88. Although Stephen speculates that a statute of 1389 may have defined murder indirectly by disallowing pardon for killings committed with malice aforethought, see note 22 infra, he agrees that murder as distinguished from all other criminal homicides achieved importance only through the series of statutes removing the benefit of clergy. 3 STEP HEN 43-44. "Malice" did not appear in the first of these four statutes, which by refusing the benefit to those who "prepensedly murder[ed]" their superiors, aimed at petty treason. $12 \mathrm{HEN}$. 7, c. 7 (1496); see STEPHEN 44. Although Stephen finds the second statute referring to "murder upon malice prepensed" and a modern critic repeats this finding, Perkins, A Re-examination of Malice Aforcthought, 43 Y ALE L.J. 537, 543 n.61 (1934), these words are absent from the statute. Instead this statute removed the benefit from cases of murder committed "in any Church. 
The meaning of malice aforethought, however, was vague. The term was first used in a statute to describe homicides not subject to pardon ${ }^{2 n}$ before appearing as the definition of murder in the statutes removing the benefit of clergy. ${ }^{21}$ In both, it appears to have meant nothing more definite than a general intention to commit a wrong. ${ }^{22}$ Although no reported judicial authority in this period seems to ascribe more specific content to malice aforethought, it clearly included felony killings which were later explained by the constructive malice doctrine, the forerunner of felony murder. ${ }^{23}$ Constructive malice imputed to

Highway, etc." 4 HEN. 8 , c. 2 (1512). The third statute removed the benefit from "wilful murder of malice prepensed" but excluded clerics of the order of sub-deacon or above from its scope. 23 HEN. 8, c. 1 , s. 3 (1531). The fourth statute eliminated this exception and removed the benefit of clergy from all murders "of malice prepensed," thus finally establishing the fundamental distinction between that offense and other criminal homicides. 1 EDw. 6, c. 12, s. 10 (1547).

20. 13 Rich. 2, No. 2, c. 1 (1389). See note 22 infra.

21. See statutes cited at note 18 supra.

22. The term "malice aforethought" first appeared in the law of homicide during the thirteenth century. Pardon was then granted for homicides found to have been committed in self-defense or by misadventure and not with "malice prepense." See 2 Pollock \& MaItLand 480-81. Agreed that malice aforethought meant little more than intentional wrongdoing in this period, Pollock and Maitland believed the term dated from the days when waylaying and ambush were common occurrences. Id. at 469 . Relying on these commentators, one writer has concluded that malice aforethought originally meant intentional wrongdoing and subsequently referred to ambush and waylaying rather than initially deriving from those situations. Perkins, supra note 19, at 545. But the first statute to use malice aforethought also withheld pardon from killings by "await" and "assault"-unnecessary additions if the term then referred to ambush or waylaying. 13 Rrch. 2, No. 2, c. 1 (1389).

About 150 years later the last statute in the series removing the benefit of clergy from murder was passed. See note 19 supra. Although Stephen disagrees, malice aforethought, as used in these statutes, meant a "wicked . . spirit." Foster, Crown LAw 256-57 (1762). Stephen's contrary conclusion that the term was used in its "popular sense" of some type of premeditated hate is based on the Statute of Stabbing. Passed in 1604, that statute removed the benefit of clergy from homicides committed by stabbing under provocation less than that of a drawn weapon. Statute of Stabbing, 1604, 2 JAc. 1, c. 8. Properly inferring that killings upon slight provocation were not murders, Stephen then illogically ascribes premeditation to malice aforethought. See 3 StEPEEN $47-48$. The factual inconsistency between premeditation and provocation does not establish that the former defined malice aforethought. Instead, in recognizing provocation as a defense to a murder charge the law merely admitted that a provoked killing is not attended by malice aforethought.

23. The first felony killing case appears to have arisen eleven years prior to the enactment of the last statute in the series removing the benefit of clergy from murder. In Mansell and Herbert's Case, 2 Dyer 128b, 73 Eng. Rep. 279 (K.B. 1536), a group of men who had unlawfully attempted to seize goods were convicted of murder when one of them struck and killed a woman with a stone thrown at another person. One year earlier, another group illegally hunting had been adjudged guilty of murder for one member's killing a gamekeeper who challenged him. Lord Dacres' Case, Moore 216, 72 Eng. Rep. 458 (K.B. 1535). Although the latter has been thought the first felony killing case, Note, 31 INo. L.J. 534 n.3 (1956), the decision may have turned on the finding that the defendants had explicitly agreed to kill whoever might resist. Since no such finding of intent to kill 
the homicide the malice aforethought of the underlying felony, thus substituting for direct proof of that mental state. ${ }^{24}$ Nevertheless, while constructive malice rested on the malice of the felony and not of the killing, it did not broaden the offense of murder. The vague content of malice aforethought would probably have been satisfied by the anti-social mind of the felon without the doctrinal rationalization provided by constructive malice. ${ }^{25}$ As a rule of law derived from a sound generalization, constructive malice met the thenexisting test of culpability based on mental state.

This was the state of the English common law which governed the American colonies. ${ }^{23}$ Despite the numerous crimes carrying the death penalty, culpability based on mental state had become an established principle determining punishment of homicide. The murderer could in no way escape capital punishment: his offense was neither justifiable nor pardonable; his literacy was irrelevant.

After the American Revolution, the Pennsylvania legislature, in accord with a constitutionally expressed policy of restricting capital punishment to the more culpable offenses, ${ }^{27}$ made a further division in the law of homicide by creating

was made in Mansell and Herbert's Case, supra, 1536 might better be considered the focal date. Note, 59 Dick. L. REv. 183, 185 (1955); cf. Note, 31 IND. L.J. 534 n.3 (1956).

Constructive malice was long described under the heading "implied malice." Using the latter term, Coke required only that the underlying act causing the homicide be unlawful. Thus, he hypothesized, human death caused by an arrow shot at a wild fowl was homicide by misadventure; were the arrow shot at a tame fowl, the offense was murder since hunting tame fowl was an illegal act. CoKE, THIRD INSTITUTE 56 (1809 ed.). In 1762, Foster required that the underlying act be a felony. Foster, Crown LAw 258 (1762). In spite of the long usage of the term "implied malice," the doctrine explaining murder convictions in these situations today is labelled constructive malice. See Royar Comimission on Capital Puntshment 1949-53, Report 382-88 (1953); cf. Commonwealth v. Bolish, $3 \$ 1 \mathrm{~Pa} .500,529,113$ A.2d 464, 479 (1955) (dissenting opinion using the term "constructive murder").

24. Under the rationale of constructive crime, the intent to commit the felony serves as intent to commit the homicide growing out of the felony. See Mirler, Criminal Law \$ SS(d) (1934); STRoud, MENs REA $169-70$ (1914). But since malice aforethought merely meant a general intention to commit a wrong, intent to commit a felony was in itself malice. See Commonwealth v. Moyer, 357 Pa. 181, 189-90, 53 A.2d 736, 741 (1947).

25. The result in Mansell and Herbert's Case, 2 Dyer 128b, 73 Eng. Rep. 279 (K.B. 1536), for example, was reached without any doctrinal rationalization.

26. During the colonial period, Pennsylvania temporarily changed the common law definition of murder. In 1683 catch-all malice aforethought was replaced by a statute requiring that the homicide be committed "wilfully or premeditately." CraARTER and Laws of the Province of Pensisylvania 144 (Linn 1879). Although a change of governors resulted in "dissolution" of this statute, $i d$. at 547 , it was substantially reenacted in 1700 , id. at 210 . The required mental state was further narrowed six years later by the substitution of "and" for "or." 2 Stat. at Large of Pennsylvania 1700-12, at 172 (1896). In 1718, however, the common law definition of murder was re-adopted. 3 id. 1712-24, at 199, 200-02.

27. Section 38 of Pennsylvania's first constitution provided: "The penal laws, as heretofore used, shall be reformed by the future Legislature of this State, as soon as may be, and punishments made in some cases less sanguinary, and in general more proportionate 
two degrees of murder. In 1793 the Senate of that state passed resolutions limiting capital punishment to murder in the first degree ${ }^{28}$ and providing lesser punishment for that of the second degree. The latter encompassed the common law definition of murder, requiring only malice aforethought. ${ }^{20}$ First degree murder had in addition to be willful, premeditated and deliberate. ${ }^{30}$ Thus a mental state characterized by a design to kill fundamentally distinguished the differently punished degrees of murder. But the bill embodying the Senate resolutions was amended to include felony murder as a first degree offense and was finally passed in this form. ${ }^{31}$ The Pennsylvania definition of felony murder-murder committed in the course of arson. rape, robbery or burglary-was substantially reproduced in the criminal colles of thirty-five other jurisdictions now recognizing two degrees of murder.

IVith the enactment of statutes simultaneously creating degrees of murder and labeling felony murder a first degree offense, the principle of culpability based on mental state has been subserved and subverted at the same time. Constructive malice provided proof of the required mental state for what has since become second degree murder, malice aforethought; felony murder, on the other hand, is punishable as first degree murder. Furthermore, unlike the relation of constructive malice to common law murder, felony murder broadens the scope of first degree murder by supplying proof of a mental state in law that may not exist in fact. The mental state of first degree murder is more specific than malice aforethought. Willfulness, premeditation and deliberation are highly partictlarized requirements, constituting in combination a design to kill directed against a selected individual. ${ }^{32}$ Were this characteristic of first degree murder construed as a general state of mind like malice aforethought.

to the crimes." Pa. Const. $\S 38$ (1776), 9 Stat. at Large of Pennsylvania 1776-79, at 585,600 (1903). Fourteen years later, Pennsylvania adopted a new constitution which contained no comparable section. Nevertheless, the spirit of reform continued. Keedy, History of the Pennsylvania Statute Creating Degrees of iIurder, 97 U. PA. L. Rev. 759, 768 (1949).

28. The Resolutions also allowed the death penalty for high treason. $3 \mathrm{~J}$. of SENATE 114 (Pa. 1793), quoted in Keedy, supra note 27, at 771. But the final draft of the bill embodying the Resolutions made only first degree murder a capital crime. 4 J. of SENATE 80 ( $\mathrm{Pa} .1794)$, quoted in Keedy, supra note 27, at 772.

29. Murder in the second degree was defined as "all other kinds of murder." $3 \mathrm{I}$. or Sexate $114(\mathrm{~Pa} .1793)$, quoted in Keedy, supra note 27 , at 771.

30. The resolutions also denominated killings committed by poison or lying in wait murders in the first degree. Ibid. But these are merely methods of killing in which premeditation and deliberation are inherent.

31. The amendment added the phrase "or which shall be committed in the perpetration of or attempt to perpetrate any arson, rape, robbery or burglary" to the definition of first degree murder. 4 J. of SenATE 80 ( $P$. 1794), quoted in Keedy, supra note 27, at 772.

32. Although premeditation and deliberation may no longer retain their classic meaning, intent to kill formed prior to the act of killing nevertheless remains essential. MoRELAND, LAw OF Honicide 209 (1952) (hereinafter cited as MoReland), and sources therein cited. Intent to kill must necessarily be directed at a given individual or individuals. This does not mean that the person killed must be the intended person. When the 
the existence of degrees of murder would be meaningless. True, when the design to kill of first degree murder can be proved on the part of the felon killer, felony murder would operate as did constructive malice under the common law. But though a general intention to do wrong accompanies commission of a felony, not every arsonist, rapist, robber or burglar has formed a specific design to kill. By eliminating inquiry into whether such design in fact exists, the felony murder doctrine thus stretches first degree murder beyond the limits of its required mental state. This indiscriminate grouping of offenses characterized by a specific design to kill with crimes marked by the commission of a felony undermines the principle of culpability based on mental state. . Iccordingly, felony murder should be abolished. ${ }^{33}$ This conclusion, moreover, does not depend on whether the objective of the criminal law is retribution and the righting of wrongs, deterrence and the prevention of future criminality, or reformation and the offender's rehabilitated return to society. Basic to that law is the principal that punishment, whatever its theoretical justification, should be proportionate to culpability.

Abolition of the felony murder doctrine need not make irrelevant evidence that the homicide occurred in the course of a felony. Such proof would still establish catch-all malice aforethought and hence justify conviction for second degree murder. ${ }^{34}$ Should first degree conviction be sought, however, the prosecution would have to meet the requirement that premeditation and deliberation nccur prior to the killing. ${ }^{35}$ Where the killing during a felony is an instinctive response to the act of the victim, conviction for first degree murder may not be possible unless premeditation and deliberation are found at some point prior to the fatal movement. Nevertheless, present notions of premeditation and deliberation could be met in certain felony killings without the doctrine. The felon who sets fire to an inhabited building knowing that the occupants cannot escape may be considered to have premeditated and deliberated their death. The robber and the burglar, on the other hand, are less likely to contemplate the death of those at the scene of their crimes.

The premeditation and deliberation requirements could conceivably be manipulated, however, to bring the acts of each of these felons within first degree murder. Thus the robber and the burglar could be deemed to have designed to kill those who obstructed commission of their felonies even though

actual victim is not the intended victim, a murder conviction may be secured under the doctrine of transferred intent. See Morkland 19-20; 2 Blackstone, Comimentaries $\approx 200-01$.

33. Although not within the scope of this Note, statutes prescribing first degree murder punishment as a matter of course for certain dangerous acts would be subject to similar criticism. See, e.g., 3 Conn. Gen. Stat. \$ 8351 (1949) (providing first degree punishment when death caused by tampering with railroad).

34. See text at note 29 supra; cf. Commonwealth v. Moyer, $357 \mathrm{~Pa} .181,189-90,53$ A.2d 736, 741 (1947).

35. Although premeditation and deliberation may occur just short of simultaneously with the killing, they must still precede the act. Morelaiv 209. 
- unlike setting fire to an inhabited building-these felonies could be consummated without loss of life. But manipulation of so elusive a concept as mental state is difficult to control and in practice may lead to confusion of premeditation and deliberation with causation alone. The arsonist, for example, could be convicted of first degree murder whether or not the building was inhabited if a not too remote death occurred in the blaze. ${ }^{36}$ Since the homicide was in fact "caused" by the arson, the law could imply that the arsonist had intended the natural and probable consequences of his felony, and had thus "premeditated and deliberated" the homicide. The same reasoning could be applied to any dangerous felony. Should causation so characterize first degree murder, the mental state of that offense would become indistinguishable from malice aforethought, thus merging degrees of murder. ${ }^{37}$

The mental state of first degree murder could be preserved and first degree convictions still secured even absent the felony murder doctrine by recognizing that the specific design to kill may be ancillary to the purpose which the homicide serves. The typical first degree murder is characterized by a mental state in which design to kill is at one with the primary purpose of the crime. In contrast, the arsonist, robber or burglar may form a design to kill which is ancillary to the commission of a felony, his primary purpose. Yet despite this ancillary-primary dichotomy, the design to kill in order to accomplish primary purpose is common to both. ${ }^{38}$ Thus, like the arsonist of an inhabited building, the armed robber who will shoot to kill in order to perfect his robbery has

36. Based essentially on a causation theory, this was the result recently in Commonwealth v. Bolish, $381 \mathrm{~Pa} .500,113 \mathrm{~A} .2 \mathrm{~d} 464$ (1955). Although reversing on other grounds, the court declared a first degree murder conviction proper where an accomplice's death was caused by his own neglect in setting fire to an empty house. See Commonwealth $v$. Lowry, $374 \mathrm{~Pa} .594,98 \mathrm{~A} .2 \mathrm{~d} 733$ (1953), upholding first degree murder conviction where defendant's only participation was driving the get-away car.

37. If the punishments were also unified, degrees of murder would of course no longer exist. Felony killings would then be governed by the constructive malice doctrine and the principle of culpability based on mental state met. It is not capital punishment of felony killings which violates culpability but equating crimes characterized by design to kill as well as malice aforethought with those involving malice aforethought alone for purposes of imposing such punishment.

38. Design to kill in ancillary purpose established, the suggested analysis would not differentiate between the primary purpose to accomplish a felony and that to commit a misdemeanor. This differs from the present view. Killings committed in the course of misdemeanors today produce only manslaughter convictions in many American jurisdictions. Miller, Crininal Law \$ 93(a) (1934); Moreland 240-45.

But design to kill in ancillary purpose should not justify first degree murder conviction unless the primary purpose is unlawful. Building a skyscraper, for example, invariably costs human life. The entrepeneur who undertakes this lawful primary purpose could conceivably be thought to have formed a design to kill in ancillary purpose. Yet his primary purpose so contributes to the public good as to negate any criminal liability for the deaths which in fact result. Legislation imposing criminal liability in such cases would seek to remake the world as well as the law which presently regards such inevitable loss of life justifiable. See Michael \& Wechsler, A Rationale of the Law of Homicide: 1,37 Colum. L. Rev. 701, 746 (1937). 
formed a design to kill in ancillary purpose. An unarmed robber fleeing from a resisting victim, however, does not entertain such design; nor does the arsonist who sets fire to a building with no cause to believe it is inhabited. When the homicide is the act of defendant's accomplice, proof of defendant's design to kill should remain essential to first degree conviction. This requirement necessitates inquiry into the common plan in order to avoid first degree conviction where design to kill is personal to the accomplice and not shared by defendant. ${ }^{39}$ Under this approach, design to kill is essential to all first degree convictions, malice aforethought to second degree offenses: the principle of culpability is thus retained as the measure of punishment for criminal homicide.

39. A concept similar to felony murder might, however, still be retained in the form of the vicarious criminal liability of conspiracy law. Under the rule of Pinkerton v. United States, 328 U.S. 640 (1946), a conspirator may be convicted for a substantive offense committed by his co-conspirator in furtherance of the illegal agreement. If the doctrine is applicable, a first degree murder by one conspirator in furtherance of the conspiracy could be attributed to his co-conspirators. In an agreement to commit a dangerous crime, the requirement in Pinkerton that the criminal act, in this case death, be foreseeable would be met. For a criticism of the Pinkerton rationale, see Note, 56 YALE L.J. 371 (1947). 